trace any connexion with them of Newcomen or of the "Proprietors of the Invention for Raising Water by Fire" who had exploited the engine. The paper was accompanied by a valuable map of the coal field showing the sites of the engines. In Prof. Rne's paper it was shown that interchangeable manufacture had begun with firearms early in the nineteenth century and had afterwards spread to clocks, watches, sewing machines, bicycles and motor-cars. of all the products of modern industry, the motor-car has pushed interchangeable manufacture furthest, and to the benefit of the widest public.

\section{Low Temperature Carbonization Plant}

THE recent opening by the Duke of Kent of a new plant erected near Chesterfield by Messrs. Low Temperature Carbonisation Ltd. has once again directed public attention to the commercial possibilities of carbonizing coal at comparatively low temperatures (about $600^{\circ} \mathrm{C}$.). This method of treating coal has as its main product a smokeless fuel which can readily be burned in any open grate, and in consequence is a valuable contribution towards a solution of the important problem of reducing atmospheric pollution. In addition, the process yields as by-product a tar from part of which a fuel suitable for use in Diesel engines can be prepared and a motor spirit of high antiknock value. The tar is also amenable to treatment by hydrogenation for the production of further motor spirit if desired. In view of a possible national emergency, there is a tendency, particularly among those not acquainted with all the relevant details, to stress the value of low temperature carbonization as a source of homeproduced motor spirit. It is, therefore, well to bear in mind that although any method of producing oil or spirit from coal is of national importance, the spirit is in this case only a by-product, and that even if all the tar were hydrogenated to produce additional motor spirit, the total yield would be extremely small when compared with the quantity now imported.

\section{Centenary of the University of Athens}

The University of Athens is the richer to-day by the congratulations of the world of learning on its centenary. Elaborate celebrations have marked this event, which was enhanced by the active participation of H.M. the King of Greece, members of the Government, of the Church and of the Services, the French Minister of National Education, and 150 delegates representing eighty foreign universities. Eloquent addresses, official receptions, musical festivals and classical performances added to the splendour of the occasion. During the past hundred years, the University of Athens has grown from a small establishment with fourteen students, to a mighty seat of learning with nearly ten thousand students of both sexes, an imposing list of professors, and manifold extensions, laboratories and institutes as additions to the original faculties. Parallel with the development, learning has found in Athens the old spirit which made the town famous throughout the classical and Byzantine periods. To-day, science and letters are steadily pursued by a band of investigators who have made substantial contributions to knowledge. To give just one example, mathematicians are familiar with the names of Hatzidakis, Zervos, Sakellariou and Eginitis. Even the history of science is represented by Prof. Stephanidis, who has many important monographs to his credit. If the English language and literature were not hitherto adequately represented, the omission has been made good by the creation of a Byron chair, which was announced as a gift of Great Britain to the most ancient seat of learning of Western civilization.

\section{Witchcraft in Bechuanaland}

WIDESPREAD interest has been aroused by the trial for witcheraft of Bagakgametsi, the former wife of Tshekedi, son of Khama, and regent chief of the Bamangwato tribe. This chief, it will be remembered, earned notoriety a little while ago for inflicting punishment on a white man, as it was held, illegally, and was deprived of his chieftainship in consequence. In February 1936 he married his cousin, Bagakgametsi, but secured a divorce from her on March 7 of this year. She is now twenty-seven years old, and was described by Sergeant Lewis, the prosecutor in the present case at Serowe, as "an educated woman". With her were accused two men, who are described as witch-doctors. The offence alleged was "practising witchcraft calculated to injure the Queen-Mother, Semane" ; but it was asserted in evidence, as reported, that Bagakgametsi herself was in fear, or stated that she was in fear of witchcraft by the Queen Mother, and consulted her two co-defendants to verify her suspicion and secure protection. One witch doctor in giving evidence in defence stated that he blew on a horn and threw the bones - the usual divinatory procedure in such cases-and said, "If Semane is bewitching Bagakgametsi she should die from blood". He added that Semane would die within two months. The other witch doctor said that the woman came to him for medicine and said she was afraid that Semane, who was jealous of her, would kill her. On the other hand, it was alleged by the prosecution that Bagakgametsi had asked one of the men for a poison root to get rid of the Queen Mother so that she alone should share Tshekedi's power. The verdict was "guilty", and a fine of $£ 50$, or twelve months imprisonment was imposed. The case is interesting as illustrating the strong hold of a belief in witcheraft on this people, even among the more enlightened, as. well as the illogical working of the attempt to suppress. the belief, which concentrates on the witch doctor, who though in many instances undoubtedly fraudulent, is at least working against an anti-social force which in such circumstances as these goes free. The British code, however, does not recognize witchcraft. as such.

\section{Synthesis of Large Molecules}

Aт the Friday evening discourse at the Royal Institution on April 23, Prof. H. Mark discussed "The 
Synthesis of Large Molecules". In Nature, all organized objects consist of large molecules. The great importance of the natural highly polymerized substances has led to the conclusion that very valuable mechanical and physiological behaviour is associated with these macro-molecules. Therefore the industries concerned with synthetic rubber, artificial silk and synthetic resins have worked out a number of synthetic high polymers, which are, in fact, of great use in making insulators, fibres and solid materials of high resistance and valuable properties. It appears that the kinetics of polymerization reactions is very complicated, but one can already distinguish three main processes which play an important role in every polymerization reaction. First a nucleus of high reactivity must be built. This can be done by a thermal collision of high energy, or photochemically, or by means of a catalytic agent. The production of these nuclei requires a high activation energy, and is therefore rather slow. The nuclei react quickly with the molecules of the monomeric substance and grow with rather high velocity stepwise to a chain. The activation energy of the growing reaction is low (about 5,000 cal./mol.) and therefore the probability of the growth is large. The chains would grow infinitely if there were not break-up reactions of different kinds. There is the possibility that the growing of the chains may be ended by lack of monomeric substance; it is possible that the decreasing steric factor of the association reaction may diminish the velocity of chain growth to a very low rate, and one must consider that different sidereactions may break up the chains suddenly. In the case of styrene, we have succeeded in distinguishing these three different stages and developing a reaction mechanism which seems to be in fair agreement with the experimental data.

\section{Recent Acquisitions at the Natural History Museum}

Among recent additions to the Zoological Department at the British Museum (Natural History) is a specimen of the pigmy scalytail of West Africa received from the Basle Museum. The Department has also acquired a large number of small mammals and birds from Yugoslavia collected by $\mathrm{Mr}$. V. Martino. This collection, comprising a number of new forms, is of considerable scientific importance and will help to fill one of the chief gaps in the study collections of mammals and birds. An important purchase for the Department of Entomology is the remainder of the Fruhstorfer collection of butterflies. 13,799 specimens, comprising the Lycænidæ and Hesperiidæ, were purchased by the Trustees in 1933, and a small section of the collection (the oriental Nymphalidæ) have in the interval been sold to the Paris Museum. The balance now acquired.consists of 48,677 specimens, of which about 3,000 are the actual specimens upon which the original descriptions of the species were based. The Mineral Department has been given by Mr. J. D. Hague a specimen of native gold in beautiful bright crystals, from the North Star mine, California. Mr. Felix F. Wilson has presented a small collection of gold which has been picked up from burns at Leadhills, in Lanarkshire, by the late Mr. Thomas Newbiggin, who was for many years engaged in mining there. A magni. ficent, clear blue, step-cut, flawless blue topaz, 614 carats in weight, from Brazil has been bought. Owing to the easy cleavage of this mineral, it is seldom that a coloured stone of this size is so free from flaws.

\section{Fourth International Grassland Congress}

ThE fourth International Grassland Congress is to be held in Great Britain on July 8-23 under the presidency of Prof. R. G. Stapledon. The paper. reading sessions will be held in Aberystwyth on July 14-18. Before and after these sessions, delegates will be shown the leading types of grassland in Great Britain, in a tour from Oxford to Aberystwyth and from Aberystwyth to Edinburgh. Fifteen plenary papers are to be presented to the Congress by delegates from Great Britain, Sweden, Germany, Italy, Fin. land, United States, Canada, Australia, New Zealand and South Africa. The remaining papers will be read to sectional meetings of the Congress, which will deal with the following aspects of the grassland problem : (1) grassland ecology, (2) seeds mixtures, (3) plant breeding and seed production, (4) fertilizers, (5) nutritive value and fodder conservation, and (6) pastures. Full details regarding plans for this Congress and a list of all papers to be presented are obtainable from the Joint Secretaries, Fourth International Grassland Congress, Aberystwyth. Particular attention is directed to the closing dates for receipt of applications (May 15 and June 19, according to the option selected).

\section{The Parliamentary Science Committee}

The latest addition to the constituent bodies of the Parliamentary Science Committee is the British Institute of Radiology. For some time past the Committee has been engaged in investigating how the Patent Office Library could be brought up to date in such a manner as to serve the interests and convenience of the public who make use of that Library. The British Science Guild undertook a similar inquiry some years ago, and the Parliamentary Science Committee made its report the starting point for the investigation. A report has been completed, and the Parliamentary Science Committee has been in communication with the Chartered Institute of Patent Agents. Dr. Leslie Burgin, M.P. (Parlia. mentary Secretary of the Board of Trade), has now consented to receive a deputation from the Parliamentary Science Committee on the subject on May 3. The deputation will be introduced by Sir Arnold Wilson, the chairman of the Committee, and it will include two or three members of parliament who are also members of the Committee.

\section{The Mellon Institute}

THE new building of the Mellon Institute, Pitts. burgh, will be dedicated on May 5-9. At the formal dedication of the building in the afternoon of May 6 